\title{
MENINGKATKAN MOTIVASI BELAJAR PADA KOMPETENSI DASAR PERKALIAN DAN PEMBAGIAN MELALUI METODE SNOWBALL DRILLING DI KELAS V SD NEGERI 067092 MEDAN MAIMUN 2018
}

\author{
Rusland Sirait ${ }^{1}$ \\ Surel: ruslansirait@gmail.com
}

\begin{abstract}
This research was conducted with the aim of increasing student learning motivation by using the Snowball Drilling method on Mathematics subjects in the subject of multiplication and fraction division. The type of research used is Classroom Action Research (CAR) conducted using 2 cycles. The research subjects were all students of Class V of SD Negeri 067092 Kec Medan Maimun with 34 students consisting of 14 female students and 14 male students. Data collection techniques used were questionnaires and observations Data analysis techniques in this study used qualitative analysis by describing the percentages in each cycle.
\end{abstract}

Keywords: Learning Motivation, Snowball Drilling Method

\begin{abstract}
ABSTRAK
Penelitian ini dilakukan dengan tujuan untuk meningkatkan motivasi belajar siswa dengan menggunakan mtode Snowball Drilling pada mata pelajaran Matematika pokok bahasan perkalian dan pembagian pecahan. Jenis penelitian yang digunakan adalah Penelitian Tindakan Kelas (PTK) yang dilakukan dengan menggunakan 2 siklus. Subjek penelitian adalah seluruh siswa Kelas V SD Negeri $067092 \mathrm{Kec}$ Medan Maimun sebanyak 34 orang siswa yang terdiri dari 14 orang siswa perempuan dan 14 orang siswa lak- laki. Teknik pengumpulan data yang digunakan adalah angket dan observasi Teknik analisa data dalam penelitian ini menggunakan analisis kualitatif dengan menguraikan persentase- persentase pada setiap siklus.
\end{abstract}

Kata Kunci : Motivasi Belajar, Metode Snowball Drilling

\section{PENDAHULUAN}

Pelajaran

matematika

merupakan pelajaran wajib yang harus diikuti oleh setiap siswa baik dari tingkat pendidikan SD, SMP, SMA maupun pada tingkat Perguruan Tinggi, yang telah ditetapkan dalam kurikulum Pendidikan Nasional karena pendidikan matematika merupakan pendidikan yang sangat akrab dengan masalah- masalah dalam kehidupan sehari- hari sehingga pelajaran tersebut sangatlah penting untuk dipelajari baik dari berbagai tingkat pendidikan. Namun pada kenyataannya,manfaat tersebut tidaklah sesuai dengan apa yang 
diharapkan karena masih banyak siswa yang tidak mengerti akan pentingnya mempelajari matematika dan kurang ketertarikannya dalam mempelajari ilmu matematika itu dengan berbagai macam dalih sehingga sebagian besar siswa SD tidak terampil dalam memecahkan persoalan-persoalan matematika yang diberikan.

Berdasarkan hasil observasi yang dilakukan di Kelas V SD Negeri No. 067092 Kec Medan Maimun, didapatkan bahwa sebagaian besar siswa memiliki motivasi yang rendah dalam mempelajari pelajaran matematika. Hal ini terlihat dari ciri- ciri yang ada berupa: kurangnya perhatian siswa pada pelajaran yang diberikan, semangat juang dalam menghadapi masalah rendah, mengerjakan sesuatu merasa seperti membawa beban berat, sulit untuk bisa "jalan sendiri" ketika diberikan tugas, adanya ketergantungan kepada orang lain, adanya usaha yang dilakukan jika dalam kondisi "dipaksa", kurangnya daya konsentrasi, cenderung menjadi pembuat kegaduhan serta suka berkeluh kesah dan pesimis ketika menghadapi kesulitan. Sejauh ini, pihak guru kurang mampu menemukan solusi yang tepat dalam menghadapi kondisi siswa yang seperti ini sehingga kondisi yang sama akan terus berulang dan berlanjut ketika menjumpai pelajaran yang sama.

Dengan adanya metode pembelajaran tersebut, diharapkan teciptanya suatu perubahan yang positif di dalam diri siswa.Untuk mengatasi permasalahan yang terjadi, peneliti merancang usaha meningkatkan motivasi belajar siswa dengan menggunakan metode Snowball Drilling.

Metode Snowball Drilling merupakan metode pembelajaran yang aktif, inovatif, kreatif, efektif dan menyenangkan. Metode ini dilakukan dalam proses pembelajaran bertujuan untuk menguatkan pengetahuan yang diperoleh siswa dari membaca bahan- bahan bacaan sebelumnya.Metode Snowball Drilling ini memenuhi beberapa kriteria pembelajaran yang aktif, efektif, efisien, dan bermutu karena dalam proses pembelajarannya menuntut kreatifitas dan efektivitas berfikir siswa sehingga dapat meningkatkan daya serap siswa dalam mempelajari matematika.

\section{METODE PENELITIAN}

Jenis penelitian ini adalah penelitian tindakan kelas. Penelitian yang dilakukan adalah penelitian kualitatif yaitu penelitian yang menjelaskan upaya-upaya yang dilakukan untuk meningkatkan hasil belajar siswa dalam proses belajar dan mengajar.

Subjek dalam penelitian ini adalah seluruh siswa Kelas V SD Negeri No. 067092 Kec Medan Maimun yang berjumlah 34 orang siswa.

Objek pada penelitian ini
adalah operasi perkalian dan
pembagian dalam bentuk pecahan.


Sebagai alternatif tindakan yang diambil untuk meningkatkan motivasi belajar siswa pada mata matematika adalah dengan menggunakan metode pembelajaran snowball drilling. Siswa dibagi atas dua jajaran yang saling berpasangan untuk berbagi informasi kepada siswa dari pasangan yang berbeda.

\section{HASIL DAN PEMBAHASAN}

$\begin{array}{llr}\text { Kegiatan awal } & \text { yang } \\ \text { dilakukan oleh } & \text { guru } & \text { adalah } \\ \text { mengobservasi } & & \text { serta }\end{array}$

\begin{tabular}{cc}
\hline Kriteria & $\begin{array}{c}\text { Banyak } \\
\text { Siswa }\end{array}$ \\
\hline $\mathbf{8 5 \%} \mathbf{- 1 0 0 \%}$ & 6 Orang \\
\hline $\mathbf{7 0 \%}-\mathbf{8 4 \%}$ & - \\
\hline $\mathbf{5 5 \%}-\mathbf{6 9 \%}$ & - \\
\hline $\mathbf{0 \%}-\mathbf{5 4 \%}$ & 28 Orang \\
\hline
\end{tabular}

\section{Deskripsi Siklus I}

\section{a. Perencanaan}

Pada tahap ini kegiatan yang dilakukan adalah merencanakan tindakan yaitu: merancang kegiatan yang dilakukan dengan 2 siklus, mempersiapkan rencana pelaksanaan pembelajaran (RPP) yang berkarakter dengan menggunakan metode Snowball Drilling, lembar observasi untuk mengetahui kondisi siswa maupun guru ketika proses belajar mengajar sedang berlangsung, membuat tes dalam bentuk pilihan berganda pada selembar kertas, menyediakan bolabola sebagai sarana dalam pemberian latihan. Mendisain alat peraga yang mengidentifikasi keadaan sekolah dan ruangan yang akan dijadikan sebagai tempat peneltian. Selain itu, peneliti juga menyebarkan angket dengan menggunakan daftar ceklist kepada siswa kelas V untuk mengidentifikasi masalah- masalah yang ada dan terjadi di saat diberikan pengajaran pada pelajaran Matematika.

\section{Tabel 1. Motivasi Belajar Siswa}

\section{Berdasarkan Nilai Angket Pada} Kondisi Awal

disesuaikan dengan kondisi kelas dengan belajar mandiri. Sebelum pembelajaran dimulai peneliti menjelaskan metode pembelajaran yang akan digunakan.

\section{b. Pelaksanaan}

Tahap pelaksanaan ini, guru menerapkan metode Snowball Drilling pada materi yang diajarkan berupa perkalian bilangan pecahan. Guru melakukan Sikus I Pertemuan I pada jam pelajaran yang pertama yaitu pukul 07.15- 08.30 WIB.

Pada kegiatan pendahuluan, guru mengabsen siswa dan memberikan motivasi belajar sebelum kegiatan belajar berlangsung. Guru memberikan appersepsi dengan menanyakan pelajaran yang telah lalu yaitu " $9 \mathrm{x} 8=$ dan $56: 8=$ “ dan peneliti menyampaian tujuan pembelajaran yaitu : agar siswa mampu menyelesaikan masalah perkalian bilangan dalam bentuk pecahan.

Pada kegiatan inti, guru melakukan tanya jawab yang berkaitan dengan topic pelajaran 
yang akan dipelajari berupa perkalian pecahan “ $\frac{2}{3} \times \frac{1}{3}=\ldots$ dan $\frac{3}{5} \times \frac{1}{2}=\ldots$ “. Kegiatan ini dimaksudkan agar mengaktifkan motivasi siswa sebelum kegiatan belajar mengajar berlangsung. Perwakilan siswa menjawab pertanyaan yang diajukan peneliti dengan menuliskan jawaban di depan papan tulis.

Pada kegiatan akhir, guru bersama dengan siswa meluruskan kekeliruan pada jawaban siswa dan siswa bersama- sama menyimpulkan materi pelajaran. Guru memberikan motivasi kepada siswa sebelum pelajaran selesai agar siswa terus belajar di rumah dan berusaha menyukai pelajaran Matematika. Di akhir pelajaran, guru memberikan PR dan menutup pelajaran dengan mengucapkan salam.

\section{c. Pengamatan}

Pengamatan dilakukan guna memantau keefektifan tindakan yang diberikan pada kegiatan belajar mengajar berlangsung dan mengamati kesesuaian perencanaan dengan pelaksanaan yang terjadi di lapangan. Observasi ini dilakukan dengan bantuan observer (guru kelas) ketika guru melakukan pengajaran dengan memberikan tindakan berupa metode Snowball Drilling. Peneliti dan Observer bekerjasama dalam menyimpulkan hasil obeservasi dengan tujuan memberikan suatu perbaikan dan pengoptimalan pelaksanaan metode Snowball Drilling.

Tabel 2. Motivasi Belajar Siswa Berdasarkan Nilai Observasi Pada Siklus I

\section{Pertemuan I}

\begin{tabular}{cc}
\hline Kriteria & Banyak Siswa \\
\hline $\mathbf{8 5 \%}-\mathbf{1 0 0 \%}$ & - \\
\hline $\mathbf{7 0 \%}-\mathbf{8 4 \%}$ & 8 Orang \\
\hline $\mathbf{5 5 \%}-\mathbf{6 9 \%}$ & - \\
\hline $\mathbf{0 \%}-\mathbf{5 4 \%}$ & 26 Orang \\
\hline
\end{tabular}

Berdasarkan dari tabel di atas dan motivasi belajar siswa secara klasikal dijelaskan sebagai berikut:

$$
\begin{aligned}
\mathrm{P} & =\frac{\mathrm{f}}{\mathrm{n}} \times 100 \% \\
& =\frac{8}{34} \times 100 \% \\
& =24 \%
\end{aligned}
$$

Dari penjelasan di atas, dapat diketahui bahwa sebanyak 19 siswa $(56 \%)$ telah termotivasi pada
Dengan demikian dapat dinyatakan bahwa secara klasikal seluruh siswa belum termotivasi dalam mengikuti pelajaran Matematika.

pelajaran Matematika dengan menggunakan metode Snowball Drilling dibandingkan pada 
pertemuan sebelumnya. Telihat sebanyak 13 siswa (38\%) yang cukup termotivasi , 2 siswa (6\%) belum termotivasi untuk mengikuti pelajaran Matematika dan Dengan keadaan yang demikian dapat disimpulkan bahwa setengah dari jumlah siswa telah termotivasi untuk mengikuti pelajaran Matematika pada materi perkalian dan pembagian pecahan dengan metode Snowball Drill.

Tabel 3. Motivasi Belajar Siswa Berdasarkan Nilai Observasi Pada Siklus I Pertemuan II

\begin{tabular}{cc}
\hline Kriteria & Banyak Siswa \\
\hline $\mathbf{8 5 \%} \mathbf{- 1 0 0 \%}$ & - \\
\hline $\mathbf{7 0 \%}-\mathbf{8 4 \%}$ & 19 Orang \\
\hline $\mathbf{5 5 \%} \mathbf{- 6 9 \%}$ & 13 Orang \\
\hline $\mathbf{0 \%} \mathbf{- 5 4 \%}$ & 2 Orang \\
\hline
\end{tabular}

Berdasarkan hasil observasi guru di atas dapat dilihat bahwa 13 deksriptor telah mendapatkan nilai yang baik namun 2 deskriptor masih mendapatkan nilai yang cukup yaitu merangsang keberanian siswa dalam menyampaikan pendapat dan mengajak siswa untuk berpartisipasi memecahkan masalah secara bersama.

\section{d. Refleksi}

Berdasarkan dari analisis yang telah dilakukan bahwa peneliti harus merefleksikan kegiatankegiatan pengajaran dengan tujuan mengoptimalkan peningkatan motivasi belajaran siswa pada pelajaran Matematika. Adapun aspek yang harus direfleksi yaitu : a) merangsang keberanian siswa dalam menyampaikan pendapat, b) mengajak siswa untuk berpartisipasi memecahkan masalah secara bersama,c) merangsang kreatifitas siswa dalam menemukan solusi pada suatu masalah, d) pengelolaan waktu, e) suasana kelas, f) merangsang keaktifan dan rasa kepercayan diri sisw dalam menyampaikan pendapat, g) memberikan kesempatan siswa untuk melakukan bentuk kerja sama kepada teman yang lain maupun guru, h) merangsang keberanian siswa untuk menyampaikan kritikan maupun solusi pada suatu penyelesaian masalah, i) memacu daya juang siswa dengan merangsang keberanian siswa untuk bertanggungjawab dengan hasil tugas yang telah dikerjakan.

\section{Deskripsi Siklus II}

\section{a. Perencanaan}

Pada tahap ini peneliti mempersiapkan rencana pelaksanaan pembelajaran (RPP) yang berkarakter dengan menggunakan metode Snowball Drilling, lembar observasi untuk mengetahui kondisi siswa maupun guru ketika proses belajar mengajar sedang berlangsung, membuat tes dalam bentuk pilihan berganda pada selembar kertas, menyediakan bola- 
bola sebagai sarana dalam pemberian latihan. Mendisain alat peraga yang disesuaikan dengan kondisi kelas dengan belajar mandiri.

\section{b. Pelaksanaan}

Pada tahap pelaksanaan ini, guru menerapkan metode Snowball Drilling pada materi yang diajarkan berupa pembagian pecahan. Guru melakukan Siklus II Pertemuan I pada jam pelajaran yang pertama yaitu pukul 07.15- 08.30 WIB. Pada kegiatan pendahuluan, guru memberikan salam kepada siswa dan mempersiapkan siswa sebelum belajar dengan membaca doa. Siswa diberikan kesempatan untuk merapikan segala sesuatu yang ada disekitar dengan memperhatikan kondisi kelas seperti meja dan kursi agar tersusun rapi.Guru mengabsen siswa dan memberikan motivasi belajar sebelum kegiatan belajar berlangsung. Guru memberikan appersepsi dengan menanyakan pelajaran yang telah lalu yaitu $4 \frac{3}{8} \mathrm{x}$ $\frac{2}{6}=\ldots$ dan $\frac{2}{5} \times \frac{1}{3}=\ldots$ “ dan peneliti menyampaian tujuan pembelajaran yaitu : agar siswa mampu menyelesaikan masalah pembagian bilangan dalam bentuk pecahan.
Pada kegiatan akhir, guru bersama dengan siswa meluruskan kekeliruan pada jawaban siswa dan siswa bersama- sama menyimpulkan materi pelajaran. Guru memberikan motivasi kepada siswa sebelum pelajaran selesai agar siswa terus belajar di rumah dan berusaha menyukai pelajaran Matematika. Di akhir pelajaran, guru memberikan PR dan menutup pelajaran dengan mengucapkan salam.

\section{c. Pengamatan \\ Kegiatan observasi ini} dilakukan untuk memantau keefektifan tindakan yang diberikan pada kegiatan belajar mengajar berlangsung dan mengamati kesesuaian perencanaan dengan pelaksanaan yang terjadi di lapangan. Observasi ini dilakukan dengan bantuan observer (guru kelas) ketika guru melakukan pengajaran dengan memberikan tindakan berupa metode Snowball Drilling. Peneliti dan Observer bekerjasama dalam menyimpulkan hasil hasil obeservasi guna memberikan suatu perbaikan dan pengoptimalan pelaksanaan metode Snowball Drilling.

\section{Tabel 4. Motivasi Belajar Siswa Berdasarkan Nilai Angket Pada Setelah} Siklus II

\begin{tabular}{cc}
\hline Kriteria & Banyak Siswa \\
\hline $\mathbf{8 5 \%}-\mathbf{1 0 0 \%}$ & 31 Orang \\
\hline $\mathbf{7 0 \%} \mathbf{- 8 4 \%}$ & 3 Orang \\
\hline $\mathbf{5 5 \%}-\mathbf{6 9 \%}$ & - \\
\hline $\mathbf{0 \%}-\mathbf{5 4 \%}$ & - \\
\hline
\end{tabular}


Berdasarkan tabel di atas, motivasi belajar siswa secara klasikal dijelaskan sebagai berikut:

$$
\begin{aligned}
\mathrm{P} \quad & =\frac{\mathrm{f}}{\mathrm{n}} \times 100 \% \\
= & \frac{34}{34} \times 100 \% \\
= & 100 \% \\
& \text { Dengan demikian dapat }
\end{aligned}
$$
dinyatakan bahwa secara klasikal seluruh siswa sangat termotivasi dalam mengikuti pelajaran Matematika dengan menggunakan metode Snowball Drilling. Dilihat dari diagram di atas dapat dinyatakan bahwa siswa mengalami perubahan motivasi belajar yang terlihat dari setiap angket yang diisi. Hal ini terlihat dari meningkatnya motivasi belajar siswa sebelum diberikan metode Snowball Drilling dan setelah diberikan pembelajaran dengan menggunakan metode Snowball Drilling.

\section{d. Refleksi}

\section{Guru bersama observer (guru} kelas) berdiskusi untuk merefleksikan tindakan yang telah dilakukan oleh guru. Dari hasil refleksi yang telah dilakukan dapat disimpulkan bahwa tindakan berupa penggunaan metode Snowball Drilling dalam pembelajaran pada siklus II sudah secara optimal dilakukan dibandingkan pada siklus Berdasarkan dari tabel keseluruhan observasi individu di atas dapat disimpulkan bahwa pada setiap pertemuan mengalami perubahan dan peningkatan terhadap motivasi belajar siswa. Pada Siklus I pertemuan I, rata- rata siswa masih belum termotivasi, yang terlihat dari
I. Hal ini terlihat dari, banyak siswa yang fokus memperhatikan guru ketika sedang menjelaskan pelajaran, siswa tidak cepat bosan dalam mengerjakan tugas dan siswa berusaha mencari suasana yang kondusif dalam belajar serta menyukai tugas yang sulit dan menantang.

$$
\text { Dari hasil keseluruhan }
$$
refleksi yang telah dilakukan menunjukkan bahwa pembelajaran dengan menggunakan metode Snowball Drilling pada siklus II sudah optimal dan dapat diprediksikan bahwa pembelajaran Matematika dengan menggunakan metode Snowaball Drilling dapat diterapkan untuk meningkatkan motivasi belajar siswa.

\section{Pembahasan Hasil Penelitian}

Berdasarkan dari hasil penyebaran angket, dapat dilihat bahwa terdapat suatu peningkatan dan perubahan secara signifikan terhadap motivasi belajar siswa dengan menggunakan metode Snowball Drilling. Di bawah ini merupakan tabel untuk mengetahui bentuk suatu peningkatan dan perubahan motivasi belajar siswa

persentase 49,67\%. Pada Siklus I pertemuan II, siswa sudah mulai termotivasi walupun dengan criteria cukup termotivasi yang terlihat dengan persentase $70,85 \%$. Pada Siklus II pertemuan I, rata- rata siswa telah termotivasi dengan persentase $76,52 \%$ walaupun masih terdapat 9 
orang siswa dengan criteria cukup termotivasi. Pada Siklus II pertemuan II, sebagian besar keseluruhan siswa sangat termotivasi pada pelajaran Matematika dengan menggunakan metode Snowball Drilling yang terlihat dari persentase $87,64 \%$ yang terdiri dari 29 siswa $(85 \%)$ memiliki criteria sangat termotivasi , 3 siswa (9\%) memiliki criteria telah termotivasi dan $2(6 \%)$ siswa memiliki criteria cukup termotivasi .

Dilihat dari diagram di atas dapat disimpulkan bahwa setiap pertemuan motivasi belajar siswa mengalami perubahan yang lebih baik lagi. Dengan demikian metode pembelajaran yang diberikan berupa metode Snowball Drilling telah menigkatkan motivasi belajar siswa.

Tabel 5. Daftar Nilai Motivasi Belajar Siswa Secara Klasikal

$\%$

Siklus I / Pertemuan

Siklus I / Pertemuan

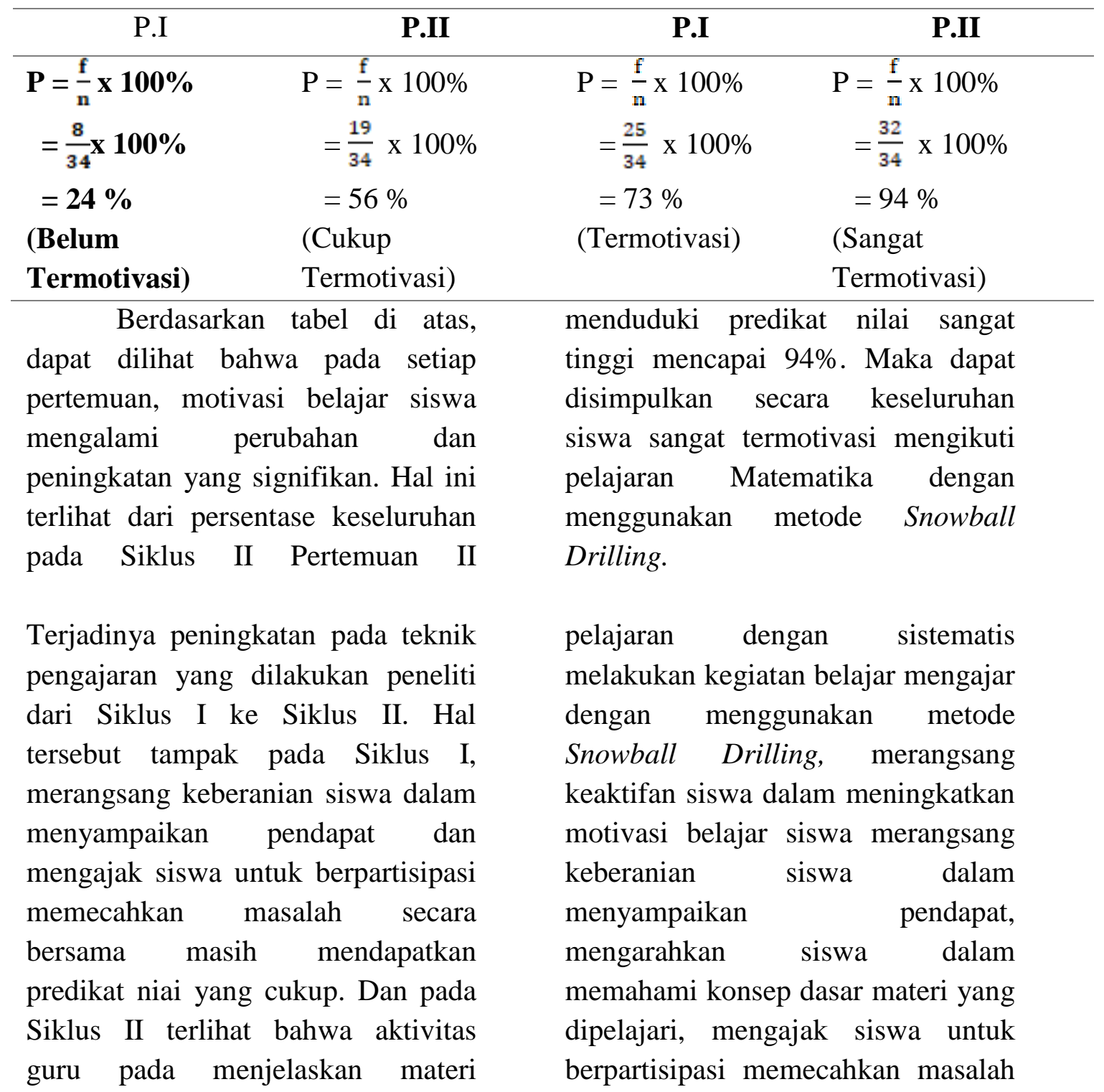


Ruslan Sirait: Meningkatkan Motivasi....

secara bersama, merangsang kreatifitas siswa dalam menemukan solusi pada suatu masalah dan memberikan motivasi kepada siswa, telah mendapatkan predikat yang sangat baik. Dengan demikian dapat disimpulkan bahwa pada Siklus II ini terjadi perubahan dan peningkatan teknik pengajaran yang dilakukan peneliti secara signifikan dan lebih baik lagi sehingga dapat meningkatkan motivasi belajar siswa pada pelajaran Matematika.

\section{Tabel 6. Daftar Nilai Angket Siswa Secara Klasikal}

\begin{tabular}{rlr}
\hline \multicolumn{1}{c}{$\%$} & \multicolumn{1}{c}{ Keterangan } \\
Kondisi Awal & Setelah Siklus II & Meningkat \\
$\mathbf{P}=\frac{\mathbf{f}}{\mathbf{n}} \times \mathbf{1 0 0 \%}$ & $\mathrm{P}=\frac{\mathrm{f}}{\mathrm{n}} \times 100 \%$ & \\
$=\frac{\mathbf{6}}{\mathbf{3 4}} \times \mathbf{1 0 0 \%}$ & $=\frac{100}{34} \times 100 \%$ & \\
$=\mathbf{1 8} \%$ & $=100 \%$ &
\end{tabular}

(Belum Termotivasi) (Sangat Termotivasi)

Berdasarkan tabel di atas, dapat dilihat bahwa pada kondisi siswa setelah diberikan tindakan mengalami perubahan dan peningkatan yang signifikan. Hal ini terlihat dari persentase keseluruhan pada Setelah Siklus II mencapai persentase yang sangat tinggi yaitu $100 \%$. Maka dapat disimpulkan secara keseluruhan siswa sangat termotivasi mengikuti pelajaran Matematika dengan menggunakan metode Snowball Drilling.

Faktor pendukung selama penelitian berlangsung adalah minat dan kemauan yang kuat pada dalam diri siswa dalam mengikuti pembelajaran Matematika yang ditunjukkan dengan upaya memberikan perhatian yang utuh pada saat guru menjelaskan dan meningkatkan daya konsentrasi siswa pada saat pembelajaran berlangsung, adanya ketertarikan siswa mengikuti pelajaran dengan diterapkan metode pembelajaran yang baru yaitu Snowball Drilling yang belum pernah diterapkan sebelumnya, adanya rasa ingin tahu yang tinggi pada diri siswa, tingkat usaha yang tinggi dalam menyelesaikan soal latihan yang diberikan oleh guru, adanya usaha siswa untuk mencari suasana yang kondusif dalam mengikuti pembelajaran dengan memilih meja dan kursi yang cocok oleh siswa.

\section{SIMPULAN}

Berdasarkan hasil dan pembahasan penelitian yang telah dilakukan pada pelajaran Matematikan dengan menggunakan metode Snowball Drilling Kelas V SD Negeri No. 067092 Kec Medan 
Maimun, maka dapat ditarik kesimpulan sebagai berikut:

1. Motivasi belajar siswa Kelas V SD Negeri No. 067092 Kec Medan Maimun pada pelajaran Matematika pokok bahasan perkalian dan pembagian bilangan pecahan dengan menggunakan metode Snowball Drilling telah mengalami perubahan dan peningkatan secara signifikan dibandingkan sebelum dilakukannya metode ini.

2. Dari hasil penelitian yang telah dilakukan oleh guru, dapat diketahui dari rata- rata motivasi belajar siswa secara individu pada setiap siklus pada pelajaran Matematika pokok bahasan perkalian dan pembagian pecahan mengalami peningkatan yaitu pada Siklus I mencapai $70,85 \%$ dan secara klasikal mencapai $56 \%$, pada Siklus II mencapai $87,64 \%$ dan secara klasikal 94\%. Rata- rata nilai angket siswa pada kondisi awal mencapai $17 \%$ dan secara klasikal mencapai $17 \%$, pada pasca siklus II mencapai $83 \%$ dan secara klasikal mencapai $100 \%$.

3. Dari hasil observasi yang telah dilakukan oleh observer pada peneliti dapat diketahui cara mengajar guru pada Siklus I mendapatkan nilai 71,66 dengan criteria baik dan pada Siklus II mendapatkan nilai 88,33 dengan criteria sangat baik.

\section{DAFTAR RUJUKAN}

Arikunto, Suhardjono, Supardi. 2012. Penelitian Tindakan Kelas. Jakarta : 2009.

Asrori, Mohammad . 2009. Psikologi Pembelajaran .Bandung : CV Wacana Prima.

Daryanto. 2010. Belajar dan Mengajar. Bandung : Yrama Widya.

Dewi, Rosmala. 2010. Penelitian Tindakan Kelas. Medan : Pasca Sarjana Unimed.

Djamarah, Syaiful. 2011. Psikologi Belajar. Jakarta : PT. Rineka Cipta.

Hardini, Isriani. 2012. Strategi Pembelajaran Terpadu (Teori, Konsep dan Implementasi). Yogyakarta: Familia.

Istarani, 2012 . Model Pembelajaran Inovatif. Jakarta : Media Persada.

Mulyasa,E.2006.Implementasi

Kurikulum Tingkat Satuan

Pendidikan. Bandung:

Remaja Rosda Karya.

Negoro, Harahap. 2005. Ensiklopedia Matematika. Bogor : Gradia Indonesia.

Purwantari, Basuki, Suryanto, Widodo. 2004. Hitunganku 
Ruslan Sirait: Meningkatkan Motivasi....

Matematika .Jakarta : Bumi Aksara.

Sabri, Ahmad . 2010. Stratei Belajar Mengajar. Jakarta: Quatum Teaching.

Sardiman. 2011. Interaksi dan Motivasi Belajar Mengajar. Jakarta: Raja Grafindo Persada.
Suprijono, Agus. 2009. Cooperative Learning Teori dan Aplikasi Paikem. Jogyakarta : Pustaka Pelajar.

Slameto. 2010. Belajar dan FaktorFaktor Yang Mempengaruhi. Jakarta: Rineka Cipta. 